\title{
Influence of Age and Gender in Acquiring Social Skills in Portuguese Preschool Education
}

\author{
Rosa Maria Silva Gomes, Anabela Sousa Pereira \\ Education Department, University of Aveiro, Aveiro, Portugal \\ Email: rosa.gomes@ua.pt, anabelapereira@ua.pt
}

Received December 20 ${ }^{\text {th }}$, 2013; revised January 23 ${ }^{\text {rd }}, 2014$; accepted February $18^{\text {th }}, 2014$

\begin{abstract}
Copyright (C) 2014 Rosa Maria Silva Gomes, Anabela Sousa Pereira. This is an open access article distributed under the Creative Commons Attribution License, which permits unrestricted use, distribution, and reproduction in any medium, provided the original work is properly cited. In accordance of the Creative Commons Attribution License all Copyrights (C) 2014 are reserved for SCIRP and the owner of the intellectual property Rosa Maria Silva Gomes, Anabela Sousa Pereira. All Copyright (C) 2014 are guarded by law and by SCIRP as a guardian.
\end{abstract}

The specificity of educational contexts as mediators of social development through positive interactions is critical to children's involvement in the kindergarten and therefore for their holistic development. The qualities of teacher-child interactions enhance the child's self-esteem and autonomy, promoting peer acceptance and providing a successful learning experience. The purpose of this study was to investigate whether the characteristic of gender and age are related to the acquisition of social skills of children attending kindergarten in a portuguese-speaking environment. The sample is composed of 581 children, age from 2 to 7 years old, who attended preschool education on average 18 months ago. Social Skills subscale (EAS) and Behavior Problems (EPC) was applied to the "Behavioral Scale for Preschool-PKBSpt" (Gomes \& Pereira, 2012), Portuguese version of PKBS-2 (Merrell, 2002), Likert-type, four response levels, which seeks to assess the social and emotional skills, and behavior problems in early childhood, with the participation of educators. The Statistical Package for Social Sciences (SPSS), version 17.0 for Windows. The main results show that there are gender differences in the level of social skills. The girls reveal behaviors based on Social Cooperation and Social Interaction. The boys show Attention Problems/Overactive and Antisocial Behavior/Aggressive. Older children have the highest average level Social Cooperation and Social Independence. In the dimensions of behavior problems, the youngest children (3 and 4 years) had higher mean values, either in the factor Attention Problem/Overactive or the Antisocial/Aggressive. Older children (6 years old) had statistically significant differences in the problems of the type Social Withdrawal and Anxiety-Somatic problems. The child's gender and age variables are important factors and should be included in educational practices, taking into account the development of social skills of children attending in preschool. Promoting articulated and differentiated development can prevent maladaptive behaviors in young adults. Finally thoughts are given on the implications of this study in the level of children's involvement within their educational contexts.

Keywords: Social Skills; Problem Behavior; Child Psychology; Preschool Education; Education Psychology

\section{Introduction}

The curriculum of Preschool Education in Portugal is governed by the Curriculum Guidelines, which adopts a perspective focused on indications for Educators and not in anticipation of learning to be performed by children. It assumes educators as builders and managers of curriculum and outlines the epistemological principles that underlie the educational options for educators, by proposing an integrated and open in different areas of the curriculum. Personal and social development is one of those areas that fall within the curriculum, not only as a necessity of children in this age group, but also as preparation for future learning.

An analysis of learning preschool education's impact in the later development of children concludes that the learning done at the level of Childhood Education is related to engagement in the tasks and social skills (Del Prette \& Del Prette, 2005). The predispositions and feelings of the child contribute significantly to expand their skills and give back success in learning. The personal, social and emotional development is important (Trianes, 2002) for the realization of children as people and for their ability to be successful learners. In our concerted efforts to raise the educational level of children it is of primary importance that we take into account how we support this development, through informed, effective and cross-curricular practices (Roberts, 2005). A study of Seçer, Çeliköz, Koçyiğit, Seçer, \& Kayılı (2010), to assess the relationship between social skills and behavior problems through PKBS Merrell (2002) and cognitive style and reflexivity-impulsivity by KRISP scale developed by Wright (1971), with 6-year-old children, attending Preschool Education showed that children with impulsive cognitive style show more behavior problems and children with cognitive style of reflexivity show more social skills. These studies show that impulsive children are less efficient than the reflective level of social skills, such as social cooperation, so 
cial interaction and social autonomy.

In modern societies, we continue to witness directly or indirectly, situations that demonstrate that many children grow in contexts and situations that constitute threats to their psychological health. When facing stressful situations and risk in their daily lives, they may develop emotional disorders and conduct problems, becoming vulnerable. However, it is observed that not all children who experience the same risk situations present problems. On the contrary, some of them are able to adapt and overcome these situations, demonstrating, among others, social skills (Cecconello \& Koller, 2000).

Social skills are learned and understood in given a situation and encompass personal, situational and cultural dimensions (Del Prette \& Del Prette, 2001). To have a good repertoire of social skills does not guarantee a socially responsible performance by itself. Campbell (1995) considers that the initial behavior problems for children in the kindergarten remain relatively stable and predicts not only problems in school but also serious health and behavioral problems in adolescence, including depression and anxiety.

In the case of negative social interactions, children tend to be rejected among peers. This pattern of social behavior will trigger a reaction from others according to the perceived default, whether positive or negative. Study Domènech-Llaberia (2008) found that physical aggression is the most common, followed by verbal aggression and that aggression among peers is associated with three-year old male children.

A study conducted in Brazil by Cecconello (2000), to assess social competence and empathy in children (6 to 9 years old), living in poverty, showed that girls are more socially competent and more empathic than boys. Likewise, the most empathetic children tend to be more socially responsible than others. In general, the studies emphasized the importance of these two characteristics as protective factors contributing to resilience and adaptation, in situations of stress and vulnerability. The girls prove to be more competent in the use of strategies of conflict resolution, using significantly less often want to retaliation or physical aggression (Walker, Irving, \& Berthelsen, 2002; Gomes, Pereira, Abrantes, Inocêncio, Merrel, \& Andreucci, 2011). The investigation (Simões \& Sanches, 2006), about age and gender in conflict resolution, with 3 to 14-yearold children, showed that age has an influence on the strategies used in conflict resolution and the older children have more elaborate types of responses. For the authors, the strategies are aggression, authority, social withdrawal and pro-social responses. Studies of Walker (2005), with 3 to 5-year-old children, showed that children aged 4 , typically developing, are able to make inferences about the beliefs and desires of others, use this information and interpret its behavior. The boys are seen as more aggressive and girls as more tolerant, dialoguing and prosocial, although the studies of Simões (2006) have not found a significant effect of interpersonal conflict on gender differences. Also the quality of interpersonal relationships among peers seems to influence social development of children from early ages.

Through positive interactions with peer groups in the early years of life, children develop the best fit social skills such as sensitivity, empathy, ability to engage in different contexts and answer social problems (Lopes, Rutherford, Cruz, Mathur, \& Quinn, 2011). Poor interactions among peers, resulting in rejection, can trigger poor social, emotional, academic adjustment, reflected even in adjustment problems in adulthood. Studies of
Asher \& Coie (1990) show that those children from preschool make their friendship choices based on observable behaviors. The pairs showing positive behaviors establish positive interactions, but the pairs showing negative behaviors are rejected and are not choosen as partners. Children who are not accepted can cause anger and aggression as a response to unfair treatment or they may choose social isolation, as a result of anxiety and social insecurity (Lopes et al., 2011).

The aim of this study was to evaluate if gender and age are related to the acquisition of social skills of children attending the preschool education, in Portuguese-speaking educational contexts.

\section{Method}

\section{Participants}

This research involved 581 children, female (52.3\%) and male (47.7\%), aged 2 to 7, who attend Preschool Education in public institutions (37.2\%), private institutions of social solidarity_-IPSS (34.6\%) and private institutions (28.2\%) on average for 18 months. Most educators who applied to the instrument were female (99.7\%), were on average 35 years with an average age of 35 , and had been practicing for an average of 10 years (see Table 1 ).

\section{Measures}

The Behavioral Scale for Preschool (PKBSpt) was adapted for the Portuguese population by Gomes, Pereira \& Merrell (2009), and validated by Gomes \& Pereira (2014) from Preschool and Kindergarten Behavior Scale, PKBS 2-Merrell (2002) and is used to evaluate the social skills and problem behaviours of children. The instruments contain 67 Likert-scale questions.

The children's social skills were assessed using the Social Skills Scale-EAS. It is a 29 -item, explaining $53.47 \%$ of the total variance and the overall value of the Cronbach's alpha coefficient was .95 . The school seeks to assess the social and emotional behaviors of children attending garden for children aged between 3 and 6. The dimensions of the Social Cooperation scale are a 12 -item, which explains $38.2 \%$ of the variance and the coefficient value of Cronbach's alpha was .92. It assesses behaviors of cooperation with peers, assertiveness and self; Social Interaction is a 7 -item, explaining $5.2 \%$ of the variance and the coefficient value of Cronbach's alpha was .76, which evaluates respect, friendliness and courtesy pipelines primarily for colleagues. The Social Independence factor is a 10 -item, which explains $10.1 \%$ of the variance and the value of Cronbach's alpha coefficient was .89. It assesses attitudes of autonomy, adaptation and acceptance both among peers and

Table 1.

Sample distribution according to age and gender.

\begin{tabular}{cccccccc}
\hline Years & & 2 & 3 & 4 & 5 & 6 & 7 \\
\hline \multirow{2}{*}{ Boys } & $\mathrm{N}$ & 3 & 37 & 78 & 106 & 49 & - \\
& $\%$ & 1.1 & 13.6 & 28.6 & 38.8 & 17.9 & \\
\multirow{2}{*}{ Girls } & $\mathrm{N}$ & 0 & 52 & 75 & 126 & 45 & 1 \\
& $\%$ & - & 17.4 & 25.1 & 42.1 & 15.1 & 0.3 \\
N (total) & & 3 & 89 & 153 & 239 & 94 & 1 \\
\% (total) & & 0.5 & 15.4 & 26.4 & 41.3 & 16.2 & 0.2 \\
\hline
\end{tabular}


between adults. Behavior problems were assessed by the Behavior Problems Scale (EPC), a 38-item, which seeks to assess the social and emotional behavior level of children attending the kindergarten.

Behavior Problems Scale (EPC), the factors are distributed by externalizing behavior problems (EPC'I) and internalizing behavior problems (EPC'I). The EPC'E consists of factor Selfcentered/Explosive and it is a 6-item, explaining $55 \%$ of the variance and Cronbach's alpha value was .87; Factor Attention Problem/Overactive is a 9-item explaining $5 \%$ of the variance and Cronbach's alpha value was .92;

Factor Antisocial/Aggressive is a 10 -item explaining 5\% of the variance and Cronbach's alpha value was .93.

Internalizing behavior problems (EPC'I) are constituted byFactor Social Withdrawal is a 6-item, explaining $45.08 \%$ of variance, with the value of Cronbach's alpha .85; Factor Anxiety/ Somatic Problems is a 7 -item, explaining $10.22 \%$ of variance, with the value of Cronbach's alpha .83.The answers were given taking into account a Likert-type, response options range from 0 (never) to 3 (often).

\section{Procedure}

The study was applied to a population of children attending preschool, whose native language is Portuguese. The sampling took place during the second quarter of 2009, in the educational contexts of Portugal, Brazil and Cabo Verde, through anonymous questionnaires and confidential self-report. For this purpose a group of educators and/or monitors was formed according to the reality of each country developing teaching activities in Kindergarten which applied the EAS and EPC questionnaire assessing children in their rooms in each of the items, supported by observations made in the last three months, as indicated in the questionnaire form.

Ethical issues were respected, participation was voluntary and each questionnaire was accompanied by explanatory information of the objectives, the conditions of research, confidentiality and anonymity of the data being secured. The SPSS (Statistical Package for Social Sciences), version 17.0 for MS Windows was used for data analysis.

\section{Results}

The results concerning the characterization of the target population, children age Preschool show a homogeneous distribution as a function of female (52.3\%) and male (47.7\%), with ages ranging from 2 to 7 years $(\mathrm{M}=4.58, \mathrm{SD}=0.96)$.

Geographically, these institutions are distributed in Portugal, Brazil and Cabo Verde: in Portugal 39.9\% of children attending preschool in the district of Aveiro, 13.9\% in the district of Porto and $11.0 \%$ in the district Santarém, in Brazil, 23.4\% attending preschool located in Botucatu, State of São Paulo and 11.7\% attending in kindergarten in the different islands of Cabo Verde.

Most educators who applied to the instrument are on average 35 years old $(\mathrm{M}=34.87, \mathrm{SD}=10.03)$, have been practicing for an average of 10 years $(\mathrm{M}=10.51, \mathrm{SD}=8.95)$ varying the service time between 1 and 33 years. The recording of observations concerning the behavior of each child was produced within the educational room (62\%) and in the kindergarten (38\%).

If we consider the parametric correlation coefficient, Pearson correlation between the EAS subscale and the gender and age variables, we find that the positive associations are weak, but significant $(p \leq .01)$, ranging between .165 and .217 , in Social Cooperation. We also found statistically significant differences between Social Interaction and gender and Social Independence although weaker $(p \leq .05)$ (see Table 2$)$.

In the EPC subscale there were significant $(p \leq .01)$ weak negative associations but between gender and the factors: Attention Problem/Overactive behavior and Antisocial/Aggressive. The variable age of children also has a weak negative association with the factor Attention Problem/Overactive and weak positive association with Social Withdrawal factor (see Table 3).

There are still strong and significant positive associations $(p \leq .01)$, among the factors of each of the scales EAS and EPC.

The results of the parametric t-student PKBSpt test showed that comparing the factors of Social Skills, statistically significant differences by gender were found. Girls had higher level of Social Cooperation mean $(\mathrm{M}=27.96, \mathrm{SD}=5.70, \mathrm{t}=-3.96, \mathrm{df}$ $=558, p=.000)$ and Social Interaction $(\mathrm{M}=15.66, \mathrm{SD}=3.84$, $\mathrm{t}=-3.29, \mathrm{df}=563, p=.001)$. Regarding EPC also statistically significant differences between genders were found. However, it were the boys who had higher mean values, either in the factor Attention Problem/Overactive $(\mathrm{M}=12.79, \mathrm{SD}=7.13, \mathrm{t}=$ $5.56, \mathrm{df}=564, p=.000)$ or the Antisocial/Aggressive factor $(\mathrm{M}$ $=9.74, \mathrm{SD}=7.41, \mathrm{t}=5.51, \mathrm{df}=562, p=.000)$ of EPC'E. These values seem to indicate that the gender variable may be associated with some of the social skills and behavior problems. However, these are not related to the problems of Anxiety/ Somatic Problems (see Table 4).

By the analysis of variance ANOVA significant differences between age and EAS factors were also found. Older children are the ones who have the highest average in Social Cooperation $(\mathrm{M}=$ 28.39, $\mathrm{SD}=6.31, \mathrm{~F}=7.13, p=.000)$ and Social Independence (M $=25.17, \mathrm{SD}=5.09, \mathrm{~F}=-3.50, p=.004)$, social skills. In the dimensions of behavior problems the youngest children ( 3 and

Table 2.

Intercorrelations among EAS and gender and age variables.

\begin{tabular}{cccccc}
\hline Factors & Gender & Age & Social Cooperation & Social Interaction & Social Independence \\
\hline Gender & 1 & & & & \\
Age & - & 1 & & & \\
Social Cooperation & $.165^{* *}$ & $.217^{* *}$ & 1 & 1 & 1 \\
Social Interaction & $.137^{* *}$ & - & $.554^{* *}$ & $.645^{* *}$ & 1 \\
Social Independence & $.088^{*}$ & - & $.592^{* *}$ & & \\
\hline
\end{tabular}

${ }^{* *} p \leq .01 ; \mathrm{N}=581 ;{ }^{*} p \leq .05$. 
Table 3.

Intercorrelations among EPC and gender and age variables.

\begin{tabular}{|c|c|c|c|c|c|c|c|}
\hline Factors & Gender & Age & $\begin{array}{l}\text { Self-Centered/ } \\
\text { Explosive }\end{array}$ & $\begin{array}{c}\text { Attention } \\
\text { Problem/Overactive }\end{array}$ & $\begin{array}{l}\text { Antisocial/ } \\
\text { Aggressive }\end{array}$ & $\begin{array}{c}\text { Social } \\
\text { Withdrawal }\end{array}$ & $\begin{array}{c}\text { Anxiety/Somatic } \\
\text { Problems }\end{array}$ \\
\hline Gender & 1 & & & & & & \\
\hline Age & - & & & & & & \\
\hline Self-Centered/Explosive & $-.089^{*}$ & - & 1 & & & & \\
\hline Attention Problem/Overactive & $-.228^{* *}$ & $-.121^{* *}$ & $.795^{* *}$ & 1 & & & \\
\hline Antisocial/Aggressive & $-.226^{* *}$ & $-.90^{*}$ & $.786^{* *}$ & $.862^{* *}$ & 1 & & \\
\hline Social Withdrawal & - & $.135^{* *}$ & $.541^{* *}$ & $.411^{* *}$ & $.433^{* *}$ & 1 & \\
\hline Anxiety/Somatic Problems & - & - & $.687^{* *}$ & $.525^{* *}$ & $.500^{* *}$ & $.670^{* *}$ & 1 \\
\hline
\end{tabular}

${ }^{* *} p \leq .01 ; \mathrm{N}=581 ;{ }^{*} p \leq .05$.

Table 4.

Comparative among dimensions and gender.

\begin{tabular}{|c|c|c|c|c|c|c|c|}
\hline Subscale & Factors & Gender & M & $\mathrm{SD}$ & $\mathrm{t}$ & $g l$ & $p$ \\
\hline \multirow{10}{*}{ EPC } & \multirow{2}{*}{ Self-Centered/Explosive } & boy & 6.66 & 4.48 & \multirow{2}{*}{2.12} & \multirow{2}{*}{560} & \multirow{2}{*}{.034} \\
\hline & & girl & 5.87 & 4.35 & & & \\
\hline & \multirow{2}{*}{ Attention Problem/Overactive } & boy & 12.79 & 7.13 & \multirow{2}{*}{5.56} & \multirow{2}{*}{564} & \multirow{2}{*}{.000} \\
\hline & & girl & 9.58 & 6.61 & & & \\
\hline & \multirow{2}{*}{ Antisocial/Aggressive } & boy & 9.74 & 7.41 & \multirow{2}{*}{5.51} & \multirow{2}{*}{562} & \multirow{2}{*}{.000} \\
\hline & & girl & 6.48 & 6.65 & & & \\
\hline & \multirow{2}{*}{ Social Withdrawal } & boy & 5.31 & 4.21 & \multirow{2}{*}{1.88} & \multirow{2}{*}{558} & \multirow{2}{*}{.060} \\
\hline & & girl & 4.65 & 4.15 & & & \\
\hline & \multirow{2}{*}{ Anxiety/SomaticProblems } & boy & 7.45 & 4.64 & \multirow{2}{*}{0.577} & \multirow{2}{*}{563} & \multirow{2}{*}{.564} \\
\hline & & girl & 7.23 & 4.57 & & & \\
\hline \multirow{6}{*}{ EAS } & \multirow{2}{*}{ Social Cooperation } & boy & 25.88 & 6.72 & \multirow{2}{*}{-3.96} & \multirow{2}{*}{558} & \multirow{2}{*}{.000} \\
\hline & & girl & 27.96 & 5.71 & & & \\
\hline & \multirow{2}{*}{ Social Interaction } & boy & 14.63 & 3.54 & \multirow{2}{*}{-3.29} & \multirow{2}{*}{563} & \multirow{2}{*}{.001} \\
\hline & & girl & 15.66 & 3.84 & & & \\
\hline & \multirow{2}{*}{ Social Independence } & boy & 24.22 & 5.09 & \multirow{2}{*}{-2.08} & \multirow{2}{*}{560} & \multirow{2}{*}{.038} \\
\hline & & girl & 25.07 & 4.60 & & & \\
\hline
\end{tabular}

4 years) were the ones with higher mean values, either in the Attention Problem/Overactive factor $(\mathrm{M}=12.60, \mathrm{SD}=6.75, \mathrm{~F}$ $=-3.29, p=.006)$ or the Antisocial/Aggressive $(\mathrm{M}=9.76, \mathrm{SD}$ $=7.41, \mathrm{~F}=-3.450, p=.005) \mathrm{EPC}$ one. Older children $(6$ years old) had significant differences in the problems of the Social Withdrawal behaviors type $(\mathrm{M}=7.04, \mathrm{SD}=4.45, \mathrm{~F}=-5.75, p$ $=.000)$ and Anxiety/Somatic problems $(\mathrm{M}=9.01, \mathrm{SD}=4.83, \mathrm{~F}$ $=4.00, p=.001)$.

\section{Discussion}

Through studies of correlations and parametric tests between the gender variables and factors of the Scale of Social Skills, it was found that girls showed more social skills based on cooperation and social interaction than boys. These results confirm some studies such as Cecconello and Koller (2000), Gomes et al. (2011).

In Scale Behavior Problems the boys have higher average values in Attention Problem/Overactive and Antisocial/Aggressive behaviors. These data seem to indicate that age and gender may be associated with some of the social skills. Behavior Problems, however, are not correlated with anxiety problems. These data can be explained by the fact that the girls prove to be more competent in the use of strategies in resolving conflicts, using significantly less often want to retaliation or physical aggression (Walker, Irving, \& Berthelsen, 2002). The results also indicate that the age of children is correlated with social withdrawal. Study (Simões \& Sanches, 2006) showed that age has an influence on the strategies used in conflict resolution and the older children had more elaborate types of responses. For the authors, the strategies were aggression, appeal to authority and avoidance or escape responses of pro-social nature.

Gomes (2012) shows that early childhood educators with more years of service develop teaching activities in public institutions which value more the social behaviors of the cooperation and social interaction kind between children. However, educators with less service time had more difficulty in dealing with children with behavior problems Self-centered/Explosive, Attention Problem/Overactive, Antisocial/Aggressive, Social 
Withdrawal and Anxiety/Somatic Problems. For instance, Zhang and Sun (2011) found reciprocal relations between externalizing problems and teacher-child conflict in preschool education. Hence the need to intervene in specialized training. Some authors (Alarcão, 2003; Alonso, 2003; Craft, 2004), show that professionalism reflects on the ability of early childhood educators to, through a critical and creative analysis, regulate their practice, deepen their knowledge and adapt their educational action to specificity of students and the school.

Educators as professionals can help in the resolution of behavioral and emotional problems in children in an educational context (Herrera \& Little, 2005; Gomes, Pereira, \& Vagos, 2013). Not to intervene in a reductive way, but proactively in order to provide children, even at an early stage, with techniques and set methods, such as cooperative learning, how to deal with anger, how to reduce stress, especially for children with predisposition to aggressive responses through relaxation techniques, self-monitoring and cognitive coping strategies, techniques of self-dialogue and troubleshooting. It's very important to create healthy and constructive environments where children participate. This must be a concern of current educational societies, because experiential components in self-regulation, such as enjoyment of an activity, would be associated with well-being.

\section{Acknowledgements}

This study was supported by Research Centre Didactics and Technology in Education of Trainers (CIDTFF), University of Aveiro.

\section{REFERENCES}

Alarcão, I. (2003). Professores reflexivos em uma escola reflexiva. São Paulo: Cortez Editora.

Alonso, L. (2003). Desenvolvimento profissional dos professores e inovação educativa: Contexto, concepções e práticas (pp. 167-185). Guimarães: Centro de Formação de Francisco de Holanda.

Asher, S. R., \& Coie, J. D. (1990). Peer rejection in childhood. New York: Cambridge University Press.

Campbell, S. B. (1995). Behaviour problems in preschool children: A review of recent research. Journal of Child Psychology and Psychiatry, 36, 113-149.

http://dx.doi.org/10.1111/j.1469-7610.1995.tb01657.x

Cecconello, A. M., \& Koller, S. H. (2000). Competência social e empatia: Um estudo sobre resiliência com crianças em situação de pobreza. Estudos de Psicologia, 5, 71-93. http://dx.doi.org/10.1590/S1413-294X2000000100005

Craft, A. (2004). A universalização da criatividade. In Cadernos de criatividade: Criatividade e educação (pp. 11-30). Lisboa: AEDC.

Del Prette, A., \& Del Prette, Z. A. P. (2001). Psicologia das relações interpessoais. Vivências para o trabalho em grupo. Petrópolis: Vozes.

Del Prette, Z. A. P., \& Del Prette, A. (2005). Psicologia das habilidades sociais na infância: Teoria e práticas. Petrópolis: Vozes.

Domènech-Llaberia, E., Jané, M. C., Corbella, T., Ballespí, S., Mitjavila, M., \& Canals, J. (2008). Teacher reports of peer aggression in preschool: Its relationship to DSM-IV externalizing symptoms. The Spanish Journal of Psychology, 11, 433-442.

Gomes, R. M., \& Pereira, A. S. (2014). Escalas comportamentais para crianças em idade Pré-Escolar, PKBSpt: manual. Aveiro: Universidade de Aveiro.

Gomes, R. M., Pereira, A., \& Vagos, P. (2013). Avaliação dos problemas de comportamento em crianças da educação pré-escolar. In B. D.
Silva, L. S. Almeida, A. Barca, M. Peralbo, A. Franco, \& R. Monginho (Eds.), Atas do XII congresso internacional galego-português de psicopedagogia (pp. 4068-4080). Braga: Universidade do Minho.

Gomes, R. M. (2012). (Re)configuração das práticas educativas na prevenção do stresse na infância. Ph.D. Thesis, Aveiro: Universidade de Aveiro.

Gomes, R. M., Pereira, A. S., \& Merrell, K. (2009). Avaliação sócio emocional: Estudo exploratório do PKBS-2 de merrell aplicado a crianças portuguesas em idade pré-escolar. In B. D. Silva, L. S. Almeida, A. Barca, \& M. Peralbo (Eds.), Actas do X congresso internacional galego-português de psicopedagogia (pp. 2759-2767). Braga: Universidade do Minho.

Gomes, R. M., Pereira, A. S., Abrantes, N., Inocêncio, L., Merrell, K., \& Andreucci, L. (2011). Avaliação das aptidões sociais e comportamentais de crianças em idade Pré-Escolar: estudo comparativo entre Portugal, Brasil e Cabo Verde. In C. S. Reis, \& F. S. Neves (Eds.), Livro de atas do XI congresso da sociedade portuguesa de ciências da educação (pp. 155-160). Guarda: Instituto Politécnico da Guarda.

Herrera, M., \& Little, E. (2005). Behaviour problems across home and kindergarten in an Australian sample. Australian Journal of Educational \& Developmental Psychology, 5, 77-90.

http://www.newcastle.edu.au/Resources/Research\%20Centres/SORT I/Journals/AJEDP/Vol\%205/v5-herrera-little.pdf

Lopes, J., Rutherford, R., Cruz, M. C, Mathur, S., \& Quinn, M. (2011). Competências sociais: Aspectos comportamentais, emocionais da aprendizagem. Braga: Psiquilíbrios Edições.

Merrell, K. W. (2002). Preschool and kindergarten behavior scales. 2nd Edition, Austin, TX: PRO-ED.

Roberts, R. (2005). Pensando em mim, mesmo e nos outros: Desenvolvimento pessoal e social. In I. Siraj-Blatchford (Ed.), Manual do desenvolvimento curricular para a educação de infância. Lisboa: Texto Editores.

Seçer, Zarife, Çeliköz, Nadir, Koçyiğit, Sezai, Seçer, Fahri, \&Kayılı, Gökhan (2010). Social skills and problem behaviours of children with different cognitive styles who attend preschool education. Australian Journal of Guidance and Counselling, 20, 91-98. http://dx.doi.org/10.1375/ajgc.20.1.91

Simões, M. C., Dias, M. L., \& Sanches, M. D. (2006). Estratégias de resolução de conflitos interpessoais: Alguns dados empíricos. In M. C. Simões, M. T. Machado, M. L. Dias, \& L. I. Lima (Eds.), Psicologia do desenvolvimento: Temas de investigação (pp. 77-93). Coimbra: Edições Almedina.

Trianes, M. V., \& Correa, A. G. (2002). Educación socio-afectiva y prevención de conflictos interpersonales en los centros escolares. Revista Interuniversitaria de Formación del Profesorado, 44, 175-189.

Walker, S., Irving, K., \& Berthelsen, D. (2002). Gender influences on preschool children's social problem-solving strategies. The Journal of Genetic Psychology, 163, 197-209. http://search.ebscohost.com/login.aspx?direct=true\&db=a9h\&AN=6 879508\&site $=$ ehost-live http://dx.doi.org/10.1080/00221320209598677

Walker, S. (2005). Gender differences in the relationship between young children's peer-related social competence and individual differences in theory of mind. The Journal of Genetic Psychology, 166, 297-312.

http://search.ebscohost.com/login.aspx?direct=true $\& d b=a 9 h \& A N=1$ 8291111\&site=ehost-live http://dx.doi.org/10.3200/GNTP.166.3.297-312

Wright, J. C. (1971). KRISP (Kansas reflection-impulsivity scale for preschoolers). Lawrence: University of Kansas,.

Zhang, X., \& Sun, J. (2011). The reciprocal relations between teachers' perceptions of children's behavior problems and teacher-Child Relationships in the first preschool. The Journal of Genetic Psychology, 172, 176-198. http://dx.doi.org/10.1080/00221325.2010.528077 